INTERNATIONAL JOURNAL OF RESEARCHES IN BIOSCIENCES, AGRICULTURE \& TECHNOLOGY ( ) VISHWASHANTI MULTIPURPOSE SOCIETY (Global Peace Multipurpose Society) R. No. MH-659/13(N) www.vmsindia.org

\title{
FISH FARMING IN AGRICULTURAL POND BY MODERN TECHNOLOGY
}

\author{
${ }^{1}$ Nimgare S.S., ${ }^{1}$ Fule U. W. and ${ }^{2}$ Telkhade P. M. \\ ${ }^{1}$ Hutatma Rasthriya Arts and Science College, Ashti, Wardha (M.S) India \\ ${ }^{2}$ Arts Commerce and Science College, Tukum, Chandrapur (M.S) India \\ Email: patankar.kargi@gmail.com
}

\begin{abstract}
Fish farming is the process of culturing edible fishes and it can be done by constructing fish ponds on agricultural land. It needs sufficient water supply throughout the year, fish food and selection of proper seeds or eggs and proper land. Fishes are important elements in maintaining the economy of nation. So modern technology is used now a days to increase the fish production. If water level and fertilizers in agriculture pond are properly maintained then normally growth of fish takes place up to $1 \mathrm{~kg}$. in 8-10 months. The income from fish selling is about Rs. $60 / \mathrm{kg}$. Fish played an important role from ancient times in providing protein rich and less fat diet to the mankind. It is one of the main components of animal protein in diet computed $11 \mathrm{~kg} / \mathrm{yr} /$ person.
\end{abstract}

Keywords- Fish, Conservation, Farming, Agriculture tank

\section{Introduction:}

Biodiversity is essential for stabilization of ecosystem, protection of overall environmental quality for understanding intrinsic worth of all species on the earth( Ehrlich and Wilson, 1991). Like preparation of agricultural land, fish pond is also prepared for fish culture and fish production. It is known as fish farming. There is need of proper selection of fish seeds(eggs), and sufficient water for complete year. Fishes are one of the important element in the economy of many nations. They have been a stable item in the diet of many people. They constitute slightly more than one half of total number of recognized living vertebrate species. There is description of an estimated 27,977 valid species of fishes (Nelson, 2006).

In India potential of fish culture is yet to be fully exploited. Fishes, being rich source of protein and high nutritive value. Extensive development of aquaculture need to be given priority after green revolution to feed ever-growing population . Success of fish culture depends apart from other factors, on selection of suitable species, sufficient water supply, quality of land etc. India stood in 7 position among the fish producing countries of the world (total production 56,05,136 tonnes and Inland production 27,80,440 tonnes) (Piska et al., 2002). China constitutes $18.56 \%$ of the fin fish and shell fish produce, where as India accounts about $3.57 \%$ of the total fish production, which is $4.949 \mathrm{~m}$ tonnes to the total world fish production ie. 9,28,66,553 tonnes (Fishing News International, 2001).

The present paper deals with the study of fish farming in agricultural pond by modern technology.

\section{Material and Method: \\ Maintenance of pond and fish conservation}

For fish farming in agricultural pond water, add $30 \mathrm{Kg}$ calcium carbonate (lime) in agricultural tank before rainy season. Fresh water is added in it. A mixture of $300 \mathrm{Kg}$ cowdung (organic sewage) and $5 \mathrm{~kg}$ super phosphate is added in pond water. This process is done before adding the fish seed. The Pungus and Cyprinus fish fries are collected from nearest fish culture center before rainy season and are added in agricultural pond before rainy season.

The doses of chemical and bio-fertilizers given in Table- 1 are added in a fish growing pond on agricultural land up to 6 months. After 6 months doses are given as per need. The use of fertilizers may increase or decrease depending on water colour, transparency, outer water supply, phytoplankton formed, zooplankton, algae, pest etc. and growth of fish.

\section{Result and Discussion:}

Quantity of fishes and the material required for its proper maintenance given in the Table-1. The large amount of food and fertilizers are need for growth of Pungus 
species. The special type floating food is prepared in different fish food production mill in Andhra Pradesh as well as paleted fish food is also available in agro-science center (Kale and Deshmukh,2017). This food is used as fish food. If water level and use of fertilizers are properly maintained then normally growth of fishes takes place up-to $1 \mathrm{Kg}$ in 8-10 months.

\section{Income from fish}

A) Total production of fish- $5000 \mathrm{Kg}$

B) Income from fish selling - Rs.3,00,000/(Avoiding labour conveyance)-Rs.60/Kg

C) Total Expenditure- Rs.1,50,000/-

D) Total profit except ExpenditureRs. 1,50,000/-

\section{Conclusion:}

The above information indicates the importance of development of fisheries. Most of the research work was on use of fry stage as stocking material in the reservoirs. Not much comparative work on the impact of stocking sizes of seed on their production in reservoirs. Hence, the present work was undertaken to know the status of fisheries, impact of stocking size of seed and development of a minor reservoir. The main focus was given to understand the key environmental parameters, biotic communities, primary productivity of the reservoir along with the impact of stocking sizes of seed on major carp production, growth, survival rates, etc.

Table-1: Quantity of fishes and required material.

\begin{tabular}{|c|l|l|l|l|}
\hline $\begin{array}{c}\text { Sr. } \\
\text { No }\end{array}$ & \multicolumn{1}{|c|}{ Item } & \multicolumn{1}{|c|}{ Quantity } & \multicolumn{1}{|c|}{ Rate (Rs.) } & Price (Rs.) \\
\hline 1 & $\begin{array}{l}\text { Fish fries } \\
\text { Pungus } \\
\text { Cyprinus }\end{array}$ & $\begin{array}{l}3000(\mathrm{No}) \\
2000(\mathrm{No})\end{array}$ & $\begin{array}{l}5000 / \text { thousand } \\
2500 / \text { thousand }\end{array}$ & $\begin{array}{l}15000 \\
5000\end{array}$ \\
\hline 2 & Lime & $30 \mathrm{Kg}$ & $10 / \mathrm{Kg}$ & 300 \\
\hline 3 & Fresh nuts & $2000 \mathrm{Kg}$ & $2 / \mathrm{Kg}$ & 4000 \\
\hline 4 & Super phosphate & $50 \mathrm{Kg}$ & $440 / \mathrm{bag}$ & 440 \\
\hline 5 & Fish food & $4000 \mathrm{Kg}$ & $30 / \mathrm{Kg}$ & $1,20,000$ \\
\hline 6 & other & - & - & 5260 \\
\hline & Total & - & - & $1,50,000$ \\
\hline
\end{tabular}

\section{References:}

Daniels, R.J.R., 2002: Fresh water fishes of peninsular India.Univercitiespress(India) private limited 35819 Hyderabad, India

Day, F, 1967: The fishes of India, vol 1 and 2, Jagamander Agency, New Delhi

Ehrlich,P.R. and O.W.Wilson,1991. Biodiversity studies: Science and Policy science, Vol.253 No.5021 pp.758-762. DOI:10. 1126/science 253. 5021.758.

Gupta, S. K and P.C.Gupta, 2006: General and applied Ichthyology(Fish and fisheries) S. chand and company Ltd, Ram nagar, $\mathrm{Pp}-$ 320326, New Delhi , India.

Kale, R.L. and S.K Deshmukh, 2017: Magzine of farmer , Agro-science center, Karad, Dist- Washim. PP- 53-54

Nelson, J.S.,2006. Fishes of the World, 4th Edition. John Wiley and Sons, Inc, pp. 601.

Pande K. and J.P. Shukla, 2007. Fish and fisheries 2 edition, PP-328-329

Piska, R.S., Devi B.S. and Chary K.D. (2000): The present status of fisheries of Ibrahimbagh, a minor reservoir of Hyderabad. Fishing Chimes, 20 (2): 41 - 43. Thingran, V.G, 1997: Fish and fisheries of India 